\title{
The Glass Ceiling Women Face: An Examination and Proposals for Development of Future Women Entrepreneurs
}

\author{
Janet L. Nixdorff
}

Theodore H. Rosen

$\bar{A}$ $s$ of 2007, there were an estimated 10.4 million businesses in the United States that were owned and operated by women. The number of women-owned firms has continued to grow at around twice the rate of all firms for the past two decades (Center for Women's Business Research, 2008). On the other hand, women comprise only 15.4 percent of corporate officers in Fortune 500 companies (Catalyst, 2007b) and, in 2003, beld only 14.8 percent of board seats in the Fortune 500 (Catalyst, 2007a).To better understand the glass ceiling faced by both female entrepreneurs and women leaders, the research on women's issues is examined from a number of different vantage points. Women's entrepreneurship and women's leadership research on leadership, decision-making, and gender differences was examined to discover commonalities. Then female single-sex education literature was reviewed for insights on developmental issues that might influence future women entrepreneurs and leaders. In this exploration of research, it was found that both women entrepreneurs and women leaders in the corporate environment tend toward the same leadership styles and ways of interacting with others; they also experience a lack of role models and possible lack of self-efficacy. The literature on single-sex education provides observations that young women may thrive in environments in which there are fewer male competitors, bold less stereotyped views on gender, hold higher aspirations, may have greater opportunities for training of leadership skills, and may have increased self-confidence that may be the result of exposure to successful women role models. Implications for future research are explored and suggestions are provided to meet the needs of developing women entrepreneurs.

Keywords: women entrepreneurs, glass ceiling, entrepreneurship education, women leaders, gender differences

As of 2007, the number of women-owned and -operated firms in the United States was estimated at 10.4 million. These firms provide jobs for 12.8 million people and generate sales of $\$ 1.9$ trillion annually. The number of womenowned firms has continued to grow at around twice the rate of all firms for the past two decades (Center for Women's
Business Research, 2008). Many of these women entrepreneurs start their new ventures after leaving the corporate environment because they have become dissatisfied with career prospects (Cormier, 2007).

Women comprise only $\mathbf{1 5 . 4}$ percent of corporate officers in Fortune 500 companies (Catalyst, 2007b) and held only 14.8 percent of board seats in the Fortune 500 in 2003 (Catalyst, 2007a). One common misperception for this lack of representation in higher organizational levels is that it takes time for women to move up through the ranks. We often hear, and in fact, know it is a truth, that there is a "glass ceiling" that meets many women as they do move up the career ladder (see e.g., Federal Glass Ceiling Commission, 1995; Catalyst, 2000; Corsun \& Costen, 2001; Davidson \& Cooper, 1992; Von Glinow \& Mercer, 1988; Powell, Butterfield \& Parent, 2002). Further, there is little evidence that women are being groomed for leadership positions in a consistent manner (Daily, Certo, \& Dalton, 1999). For example, Helfat, Harris and Wolfson (2006) found that only 6 percent of CEOs in the Fortune 1000 will be women by the year 2016. Even if women do advance in their careers, they may be subject to different expectations than their male counterparts. For example, the recent expulsion of Carly Fiorina from HewlettPackard may mirror these anomalies in corporate expectancies (Des Jardins, 2005; Loomis, 2005). The glass ceiling effect holds implications for women entrepreneurs and women in corporate positions alike.

Much has been written about the lack of female advancement in the workforce. Rather than a direct focus on diversity issues, women's socialization, or the milieu within which the organizational culture may perpetuate covert discrimination, this article approaches the topic of a glass ceiling through a circuitous route. Perhaps the glass ceiling for females, including women entrepreneurs, is the result of early gender differences in educational experiences, the perception (or perhaps, reality) of leadership style differences, or differences of a more fundamental nature. Moreover, perhaps there is value in examining the "community of women" aspect of femaleness to provide insights that would encourage women to become entrepreneurs or advance on corporate ladders. More specifically, the research on women's issues is examined from a number of different vantage points. 
First, are there clues that can be gleaned from the literature on one leadership role that is receiving increased interestthat of women entrepreneurs? Second, are there real differences in male and female leadership styles? And finally, if there are differences, would it be of value to examine early development of females by exploring the findings in singlesex education literature?

A caveat should be acknowledged regarding the literature reviewed for this article. It was not our purpose to provide a comprehensive literature review but an illustrative sampling of the three research areas: women's entrepreneurship, women's leadership, and single-sex education. Extensive literature reviews have already been done by other authors (e.g., Brush, et al., 2004; Betters-Reed and Moore, 2007; O'Neil, Hopkins, and Bilimoria, 2008; Klenke, 1996; Tidball, et al., 1999). Rather, our interest is focused on what makes women entrepreneurs different from their male counterparts. We were not looking for "average differences," as suggested by deBruin, Brush and Welter (2007); rather, we were focused on "patterns of variation" (deBruin et al., 2007). The above-raised questions directed our search in the three literature streams for research that highlighted leadership and decision-making styles, other gender differences, and early education influences. The purpose of this article is to determine if there are commonalities in the literature that will help us "connect the dots" for the education and development of future women entrepreneurs, which also leads to implications for further research directions.

This article will examine and present the commonalities found in the women's entrepreneurship and women's leadership research, and then provide an overview of findings in the female single-sex education literature. Finally, a discussion of the commonalities, implications for future research, and suggestions for practice will be provided.

\section{Women Entrepreneurs}

Women entrepreneurs are defined in general as women who have initiated a business, are actively involved in managing it, own at least 50 percent of the firm, and the business has been in operation one year or longer (Buttner and Moore, 1997); however, women entrepreneurs did not attract academic interest until the 1980s. Since then, the number of journal articles has been increasing and the scope of interest is evolving.

From a review of literature in 1999, Moore found five definitive clusters of research on women entrepreneurs: behaviors, stereotypes, and roles; performance, transitions, ownership span, and loan status; networks, the interactive approach, and affiliations; global findings on gender differences; and career typing of entrepreneurs. In a more recent literature review, Moore (2004) found the following six areas of study: women owners worldwide; roles played by social capital and mentoring; business funding and venture capital access; balance between family life and business ownership; role of technology adaptation to success; and challenges, problems, and growth strategies special to the careers of Hispanic and black female owners.

There have been a number of other, more recent, literature reviews on women's entrepreneurship since the early days (e.g., Betters-Reed and Moore, 2007; Brush et al. 2004; deBruin et al., 2007; Gundry, Ben-Yoseph, and Posig, 2002). Yet, there is still a paucity of research on women entrepreneurs (Menzies, Diochon, and Gasse, 2004), and still more needs to be understood about the female entrepreneurial experience. This lack of research and understanding is no doubt a reflection of the early stages development of the field of women's entrepreneurship. In a recent review of university library databases, less than 232 academic journal articles discussing on women's entrepreneurship from 1976 to the present were identified. Curiously, many of the articles related women's entrepreneurship experiences outside the United States, notably in developing countries such as Turkey and India.Additionally, Green, et al. (2003) reviewed 173 articles on women's entrepreneurship, and of these, only 11 appeared to address women's leadership or management style.

In the entrepreneurship literature, males are used as the model when examining issues in entrepreneurship (Baker, Aldrich, and Liou, 1997). For example, Stevenson (1990) reported that the literature provides many examples of how male experience defines entrepreneurship and how these definitions are used to predict who in a culture has the propensity to become an entrepreneur. Indeed, a predominant focus in the literature on "what makes an entrepreneur" seems to parallel early trait leadership theories. Nevertheless, Moore (1990) and others (e.g., Brush, 1992; Birley, 1989; DeCarlo and Lyons, 1979) echoed Stevenson, concluding that males' entrepreneurial experiences, behavior patterns, or values are not always appropriate for studying women's entrepreneurial activities.

Women may become entrepreneurs to have more control over their careers and futures and to avoid the "glass ceiling" so often evident in the rest of the business world, yet they are still faced with the same cultural constraints (Brush et al., 2004). When women enter self-employment they, in fact, often do so "with fewer financial assets, less experience in management and are underresourced in terms of their human and social capital" than their male counterparts (Carter, 2000, p. 329; see also Baker et al., 1997).

\section{Gender Differences and Entrepreneurship}

Some researchers have investigated gender as it applies to motivation in pre- and early-stage entrepreneurs. Kourilsky and Walstad (1998), for example, showed that both males and 
females lacked entrepreneurial knowledge in high school. While female students were more aware of their deficiencies in this area, they were less likely than males to want to start their own business. A study by Wilson, Marlino and Kickul (2004) also found these differences in intention. Further, they suggested that lack of confidence in their quantitative abilities may be a barrier for females when considering their career options. The lack of female role models was suggested as a detrimental factor in the encouragement of female students to pursue entrepreneurship as a career (Wilson et al., 2004). However, some studies indicate that even with better educational background, males move into entrepreneurship careers more often than women (Cowling and Taylor, 2001). After a literature review on the differences between male and female entrepreneurs, Birley (1989) suggested that women are beginning to feel more confident about their skills in building commercial networks and establishing credibility with various stakeholders. However, women are still often starting traditional service and retail businesses. This focus on service and retail businesses may keep them from acquiring capital.

The lack of self-efficacy in young female students apparently is often carried forward into the university setting and beyond. Wilson, Kickul, and Marlino (2007), in a follow-up study, found significant differences in entrepreneurial selfefficacy scores between male and female MBA students. The 2007 Global Entrepreneurship Monitor Report (Allen, et al., 2008) noted that "perceptual factors that reflect optimism, self-confidence, and no/low fear of failure are important predictors of women's entrepreneurship" (p. 40). Langowitz and Minniti (2007) also found a strong positive and significant correlation between self-confidence, opportunity perception, and the likelihood of starting a business. Although Mueller and Dato-on (2008) found no differences in entrepreneurial self-efficacy between male and female MBA students, they did find that gender-role orientation does exist-and that the relationship between gender-role orientation and self-efficacy is complex and multifaceted.

As to specific gender traits in entrepreneurs, Brush (1992) noted that studies of psychological traits have found more similarities than differences between female and male entrepreneurs. Other research supports this finding. As noted in Srinivasan, Woo, and Cooper (1994), researchers have found that women scored similar to men along scales of conformity, interpersonal effect, social adroitness, harm avoidance, and succorance (willingness to give assistance). The score on succorance belies the commonly held notion that women are emotional and need constant external support. Schwartz (1976), in one of the earliest studies of women entrepreneurs, also found few differences in personal attributes of men and women entrepreneurs. The research noted that gender differences appears to have focused on factors other than personality, including management skills, growth intentions, equity capital, and motivation for starting the business.

\section{Entrepreneurial Leadership Styles and Gender}

Leadership styles do appear to be differentiated between male and female entrepreneurs. Chaganti (1986), for example, noted that her sample displayed more feminine than masculine managerial styles among women entrepreneurs. Stevenson (1986) found some differences in entrepreneurial experience, but noted that these differences may not be sex based. Brush (1992) reported that male and female entrepreneurs differed in their reasons for business start-ups: timing, education, work experience, business skills, and management styles. She proposed that women view business as cooperative networks of relationships.

Regarding strategy, Brush and Bird (1996), in a study of 225 women entrepreneurs, found that their dimension of "vision" could be characterized as "innovative realism," further defined as flexibility, innovation, action oriented, changing, and inspirational. They noted that in previous studies, it was shown that males emphasize "strategy formulation," further defined as planned, long term, formalized, and strategic. In a conceptual paper, Bird and Brush (2002) further developed these findings, by proposing that these differences reflect a difference in world interpretation. Masculine values are rule based, hierarchical, and legalistic, while female values are reflected in relational decision making and care. In terms of control, women entrepreneurs value shared, wider participation in the decision-making process, which is validated by intuition and feelings.

When it comes to decision making, there are conflicting results. Although Verheul (2002) reported that there was no significant differences in gender with regard to employee participation and decision making in her study of 28 Dutch real estate entrepreneurs, she went on to note that males tend to use a moderate form of command and control, while females are more likely to involve employees in the decisionmaking process and are more personally involved with personnel. They cultivate relationships, and loyalty is important. On the other hand, Mukhtar (2002), using a survey of 5,710 small businesses in the U.K., found that female owner-managers were not only less likely to allow employees to make independent decisions, but were less likely to consult them on a regular basis. Women appear to have a more informal approach to managing on a day-to-day basis, and their business functions evolve out of people. Men, on the other hand, build their organizations around business functions. Neider's (1987) study of 52 women entrepreneurs confirmed that the organizational structures in her sample were relatively informal, and there was a reluctance to delegate responsibility in even minor aspects of business operations. The style differ- 
ences may reflect national cultural differences rather than gender differences.

Findings suggest that instead of the traditional top-down organizational chart, an image of the organizational charts of businesses of women entrepreneurs would be a wheel with the owner at the center, connected directly to each subordinate by a spoke, and the employees linked to each other along the rim (Buttner and Moore, 1997). The image clearly conveys that a centrally located entrepreneur/manager will not only have greater control over relevant resources and enjoy benefits and opportunities not always available to those on the periphery of the network, but also will be directly linked to individuals in her firm (Ibarra, 1995; Ibarra and Andrews, 1993; Moore, 1999).

Gilligan (1982) explained this structural phenomenon by noting that women's reality can be characterized by connectedness and relationships. Further, men's social orientation is positional, while women's is personal (see also Mast, 2005). The stereotypical differences between men's and women's leadership styles (which will be discussed in more detail later), also rears its head in female-owned businesses. Fagenson and Marcus (1991), for example, noted in their study that both men and women assigned more weight to masculine attributes of a successful entrepreneur. Masculine characteristics were described as competitive, active, independent, able to make decisions, resilient, feels very superior, self-confident, and stands up well under pressure. Female characteristics were described as emotional, understanding, warm, able to devote oneself completely to others, gentle, helpful to others, kind, and aware of others' feelings (Fagenson and Marcus, 1991).

Buttner (2001) offered a possible additional explanation to the above findings. She proposed that women may use a different conceptual model than has traditionally been employed in large organizations in mediating between social benefits and traditional economic gains that are sometimes conflicting goals. In particular, women may adopt a more relational approach (Miller, 1976) in interactions with employees and clients. In their own companies, women are unencumbered by the cultural influences and behavioral expectations regarding appropriate management and interpersonal styles that exist in large organizations. According to relational theory, one's sense of self and worth is grounded in the ability to make and maintain connections with others. Surry (as cited in Buttner, 2001) noted that mutual empathy is experienced as self-enhancing for women.

\section{Social Capital}

Social capital is defined as: "the goodwill available to individuals or groups. Its source lies in the structure and content of the actor's social relations. Its effects flow from the information, influence, and solidarity it makes available to the actor"
(Adler and Kwon, 2002, p. 23). One of the fundamental propositions of social capital theory is that network ties provide access to resources; they provide information channels that reduce the amount of time required to gather information (Nahapiet and Ghoshal, 1998). A second general benefit that accrues from network membership is that it provides members a sense of being in a community with shared interests, a common identity, and a commitment to the common good (Adler and Kwon, 2002). Further it can be reflective of consummatory motivations that are based on the experience of a shared destiny with others (Portes, 1998).

Relational theory would also partially explain women entrepreneurs' reliance on networks to help them manage their business and home life demands. Moore (1999) reported that networks of trusted advisers serve women entrepreneurs as confidential sounding boards for voicing concerns and sharing solutions. Entrepreneurs consider personal and emotional support, which mostly comes from spouses or significant others, far more important than financial, operational, or other types of assistance in running their businesses. Buttner and Moore (1997) found over 60 percent of the women entrepreneurs in their study viewed their work and life as a central point connected to an overlapping series of network relationships that included family, business, and society. The establishment of cooperative networks is clearly related as one of the most important factors in gaining success (Moore, 1999). Smeltzer and Fann (1989) concurred with the notion of the importance of networks for women entrepreneurs. They noted that women gain both social and instrumental support from female networks. Formalized female networks appear to be increasing in number for women entrepreneurs. For example, in just the northern Virginia region of the metropolitan Washington, DC area, there are more than 40 female networking groups (Nixdorff, 2008).

A number of studies have examined the participants that make up these entrepreneurial networks for women. Davidsson and Honig (2003) examined entrepreneurs (without regard to gender) by comparing individuals involved in nascent activities with a control group over a period of 18 months. With regard to networking activities, they found that strong ties (nuclear family and/or close friends) were strongly associated with the probability of entry into business. However, as time progressed, weak ties (loose relationships between individuals) became increasingly important and significant in predicting "gestation" and successful exploitation. In a study of gender and social network composition, Renzulli,Aldrich, and Moody (2000) found that women tended to have more homogeneous networks than men with respect to kin, and that this proves to be disadvantageous to entrepreneurial start-ups. However, gender composition of the networks yielded little significant differences. Klyver and 
Terjesen's (2007) findings somewhat refine the previous studies' conclusions by suggesting that while females in their study had significantly lower levels of males in social networks at start-up, as they proceeded through the venture phases, their networks were adapted to be similar to men's networks.

\section{Women's Leadership}

One of the most succinct definitions of leadership was proposed by Katz and Kahn (1978) as the "influential increment over and above mechanical compliance with the routine directives of the organization" (p. 528). Rost (1991) analyzed 221 definitions of leadership found in books, book chapters, and journal entries between 1900 and 1990, and concluded that the leadership definitions assumed that leadership is "rational, management-oriented, male, technocratic, quantitative, goal dominated, cost-benefit driven, personalistic, hierarchical, short term, pragmatic, and materialistic" (p. 94). This would appear to be at odds with our current understanding of leadership as influential, charismatic, visionary, innovative, and so on. Rost's own summary description of leadership today is that leadership is good management (1991).

The topic of women and leadership has, as in the case of women entrepreneurs, only been the subject of empirical research since the 1980s. Most research before that time was carried out by men, dealt almost exclusively with male leaders, and emphasized differences between male and female leaders. Since the studies and leadership theories were framed and developed through the eyes of men, the results were biased portrayals of women leaders (Klenke, 1996).

A more general complaint regarding leadership research has been the methodologies used to measure it, and this has led to distorted views of the concept. Most of the measures used on gender differences in leadership are scales that are formatted and scored in a bipolar fashion, thus forcing respondents to adopt an either/or response that precludes notions of equality (Bobko, 1985; Brown, 1979). Using this line of thought, individuals must either display masculine or feminine styles; those that display both were often considered anomalies.

Both sets of behaviors are actually indicative of effective leadership. Hart and Quinn (1993) noted "that effective leadership requires a balancing and simultaneous mastery of seemingly contradictory or paradoxical capabilities-decisiveness and reflectiveness, broad vision and attention to detail, bold moves and incremental adjustment, and a performance as well as a people orientation" (p. 544). Klenke (1996) noted that much of leadership is contextual; that is, it is shaped by situational, historical, temporal, and other factors. This builds on the idea that at any given time and any given place, leaders are very much the product of their particular era and the organization in which they exercise lead- ership. Her premise was that leadership is "shaped by culture and that definitions of leadership change from one context to the next" (p. 10).

\section{Gender Differences}

Traditionally, leaders were thought to exhibit certain traits that predisposed them to act effectively in leadership positions. Women, it was believed, lacked these traits and prerequisites: aggression, competitiveness, dominance, Machiavellianism, ambition, decisiveness, high levels of energy, tallness, a commanding voice, persistence, and assertiveness (Klenke, 1996). Female executives adhered to many of these "rules of conduct" because they were breaking new ground (Rosener, 1990). In the world of leaders, women find themselves caught in an ambivalent situation wherein they are stereotyped as "women leaders," while the prevailing leadership norms project social representations of leadership that are predominantly male (Powell et al., 2002).

Gender is often an issue when female leaders are evaluated (Apfelbaum and Hadley, 1986; Klenke, 1996). Gender acts as a filter for assessing women's leadership skills and effectiveness. In other words, evaluators are bound by their perceptual realities of gender expectations. Women leaders do not necessarily lack confidence in their leadership abilities nor the competence to function effectively as leaders, but they often experience a sense of tokenism, vulnerability, and precariousness (Apfelbaum and Hadley, 1986). Rosen (in press) discusses the concept of "perceiving disagreement" where disconnects occur when different bases of cognitive functioning result in different end perceptions of common events. These disconnects dominate conclusions and bias later behavior and thinking. Further, male decision makers believe that masculine characteristics are best suited for leadership roles and that men possess these characteristics in greater abundance than women (Powell, et al., 2002). Therefore, men are more likely to be selected for open leadership positions than equally qualified women. Male managers are also likely be evaluated more favorably than female managers who have exhibited equivalent performance (Heilman, et al., 1989; Nieva and Gutek, 1980; Powell, et al., 2002).

Klenke (1996) noted that gender provides a convenient way to categorize the world: "Since biological sex is a dichotomized category, there is a tendency for people to align psychological attributes, including personality characteristics (e.g., aggressiveness), leadership styles, and competencies, with being female or male. Gender . . . is used to designate social relations between sexes" (p.138). Further, gender stereotyping occurs most frequently when people know little about individuals except their sex.Vecchio (2002) noted that gender stereotypes function as a heuristic device that is employed in retrospective or prospective judgments. He sug- 
gested that in a work setting, respondents tend to describe their own behavior in nonstereotypical fashion. However, when subjects are asked to envision whether gender differences exist or are asked to remember past work experiences, they tend to be more likely to invoke a gender heuristic to characterize differences between leaders. In fact, research shows that "men and women tend to stereotype their own behavior according to cultural views of gender-appropriate behavior, as much as they stereotype the behavior of other groups. Social controls, more than socialization, account for people's interests and behavior" (Epstein, 1991, p.150; Eccles, 1987).

It is discouraging to note that these gender stereotypes continue. Powell et al. (2002) reported that in their 1999 study, both undergraduate and graduate business students viewed a good manager as possessing predominantly masculine characteristics. The 1999 study was a replication of a study done by these authors in 1976 (Powell et al., 1979). Despite an increase in the number of women managers in this period (from $21 \%$ in 1976 to $46 \%$ in 1999), men and women in their study still described a good manager as having masculine characteristics. However, graduates viewed a good manager as possessing less masculine characteristics over time.

Meyerson and Fletcher (2002) noted that all men are not to blame for gender discrimination. They pointed out that there are many men who do not embrace the traditional division of labor. Yet, their research shows that women tend to blame themselves for gender inequities. This feeling has been reinforced by managers who have tried to solve the problem by "fixing" women in one of three ways. Firstly, managers may provide training to teach women to assimilate by adopting more masculine attributes and learn masculine "game" tactics; secondly, they may provide mentoring programs, alternative career tracks or flexible work arrangements to obviate structural barriers; and thirdly, they may celebrate the differences by offering such activities as sensitivity training or offering women jobs where they market to women (Meyerson and Fletcher, 2002).

\section{Leadership Styles and Gender}

The literature that focuses on leadership styles as masculine or feminine notes that men utilize a command-and-control style of leadership, which emphasizes hierarchy, dominance, and competition, and characterize women's leadership style as cooperative, nurturing, empowering, and team-oriented (Klenke, 1996). McClelland (1975) suggested that men use directive behaviors while women use interpersonally oriented behavior when leading.

Loden's Feminine Leadership: Or How to Succeed in Business Without Being One of the Boys (1985) was one of the earliest books that claimed women's superior leadership potential. The author maintained there is a masculine mode of leadership based on high control for the leader, hierarchical authority, and analytic problem-solving. Women, on the other hand, prefer a feminine leadership model built on cooperation, collaboration, low control for the leader, and intuitive problem-solving. The core characteristic of the "feminine" leadership style is the reliance on emotional as well as rational data. Loden asserted that feminine leaders see the world through two different but concurrent lenses and, as a result, respond to situations on both thinking and feeling levels. Women embracing this type of leadership create a climate of cooperation, participation, and shared accountability. "Acting like a man" or "acting like a woman" has consequences for a woman leader, however. Watson (1988) found that women who enacted a dominant style were found less influential than were women who enacted a feminine style in a problem-solving simulation.

Much of the popular literature implies that women's ways of leading are more desirable and effective and should perhaps be the norm desirable for men as well in today's world of managing our heterogeneous, culturally diverse workforce. Klenke (1996) commented that

....ironically enough, the skills and traits women were once told had no place in boardrooms are the very same which now give them a leadership edge. After half a century of male-oriented research, leadership in the popular press is presented as a highly gendered domain of a different kind, with women leading more effectively because prevailing female gender stereotypes are now touted as providing an advantage. (p. 132)

Proponents of emotional intelligence recognized this advantage and have altered how leadership development activities are conducted (Goleman, 1995).

Helgensen (1990) described the differences in interpersonal relationships between male and female leaders by using two images: the hierarchy and the web. She asserted that women form flat organizations rather than hierarchical ones, and their leadership style is characterized by frequent contacts with staff members and sharing of information. The integration of female values into the leadership situation creates a web of inclusion, a circular system interconnected by an exchange of power and information. At the center of the web, is the woman leader, who stresses the importance of accessibility and maintains an open-door policy. Further, Yammarino, et al. (1997) found that female leaders form unique one-to-one interpersonal relationships and that these relationships are independent of one another and group membership.

A current view of differing styles is that of transactional or transformational leadership. Rosener (1990) noted that men 
are more likely than women to describe themselves in ways that represent transactional leadership. That is, they view performance as a series of transactions with subordinatesexchanging rewards for services rendered or punishment for inadequate performance. The men are also more likely to use power that comes from their organizational position and formal authority. The women are characterized in ways that represent transformational leadership-getting subordinates to transform their own self-interest into the interests of the group through concern for a broader goal. Moreover, they are likely to use power that comes from personal characteristics like charisma, interpersonal skills, hard work, or personal contacts rather than to organizational stature. Male leaders are more inclined to focus on the failings of their followers, rather than caring about them as individuals as women leaders tend to do (Brockner and Adsit, 1986).

Rosener proposed a third leadership style that she called "interactive leadership" because the women in her qualitative study actively worked to make their interactions with subordinates positive for everyone involved. The women encouraged participation, shared power and information, enhanced other people's self-worth, and got others excited about their work. These leaders believed that people perform best when they feel good about themselves and their work, and they tried to create situations that contribute to that feeling. Furthermore, these women tried to make people feel part of the organization. They tried to instill group identity in a variety of ways, including encouraging others to have a say in almost every aspect of work, from setting performance goals to determining strategy (Rosener, 1990).

Appelbaum, Audet, and Miller (2003) agreed that male and female leadership styles are different; however, women's styles are more effective in the context of today's team-based organizational structures. Other than socialization as a reason for this predominantly "feminine" transformational style, Korac-Kakabadse, Korac-Kakabadse, and Myers (1998), after reviewing a number of studies, suggested that individuals are more likely to use transformational leadership when they are dissatisfied with their work environment. For example, women in leadership roles dissatisfied with the predominantly nonproportional representation of women in leadership ranks may trigger women's desire to transform organizations in a way that would provide women with greater work-related satisfaction (Korac-Kakabadse, et al., 1998). Research further suggests that women in firms with few senior women were less likely to experience common gender as a positive basis for identification with other women; are less likely to perceive senior women as role models in terms of legitimate authority; are more likely to perceive competition in relationship with women peers; and are less likely to find support in these relationships (Ely, 1994), and as such, are less likely to be satisfied with the workplace.
Eagly and Johnson (1990), in a meta-analysis of 162 leadership studies, found that women tended to adopt a more democratic or participative style and less autocratic or directive style than men. A more recent meta-analysis by Eagly, Johanneson-Schmidt and van Engen (2003) confirmed these findings.

In a review of early leadership studies, Eagly, Karau, and Makhijani (1995) reported that women and men did not differ in general in their effectiveness as leaders. However, more specifically, this generalization is not appropriate in all, or even in most, settings. Very often the sex of the leader or manager does make a difference. They found that leadership roles defined in relatively masculine terms favored male leaders and that roles defined in relatively feminine terms favored female leaders. Specifically, sex differences in leader's effectiveness were significantly correlated with the "congeniality" of their roles for men or women, as measured by their "questionnaire asking respondents' judgments of competence and interest in relation to the roles" (p. 137). Statham (1987) showed that respondents perceived that women managers were both task and people oriented, while men managers were perceived as image engrossed and autonomy oriented. In addition, the respondents reported a strong preference for their gender-appropriate model, and, in fact, expressed exasperation with managers using the alternative approach.

Klenke (1996) pointed out that there is an interesting shift in findings on male/female leadership differences since the 1980s. Earlier than the 1980s, studies of gender differences were more likely to report significant differences in leadership styles of men and women, evaluations of female and male leaders, follower satisfaction with male and female leaders, leader effectiveness, and performance of female and male leaders. More recent findings, however, tend to report small or insignificant differences. The chronological split is confounded by important differences in the research methods used in earlier versus later studies as noted above.

Women tend to have lower self-confidence than men do (Lenney, Gold, and Browning, 1983; Nieva and Gutek, 1981; Ragins and Sunstrom, 1989). Differences between men and women on self-confidence may vary with the situation. Selfconfidence among women has been shown to be partially based upon comparisons of their own ability with that of others (Lenney et al., 1983). Self-confidence may be associated with seeking or using power in organizations (Goodstadt and Kipnis, 1970; Mowday, 1979). People who lack self-confidence may hesitate to seek or use power. On the other hand, those who lack or fail to use legitimate or position power may eventually develop low self-confidence. This cycle may be more of a problem for women than for men in organizations. Because women have relatively little legitimate or formal power in organizations, their positions are less likely to provide a basis for self-confidence (Ragins and Sunstrom, 1989). 


\section{Social Capital}

The differences between male and female managers may be due to the notion that men and women generally perceive the world differently and, therefore, communicate differently, as noted earlier (Gilligan, 1982). For women, the world is a network of connections where support and consensus are sought and confirmed. For men, the world is made up of individuals in a hierarchical social order in which life is a competitive struggle for success, the gaining of independence and advantage over others, and avoiding the loss of power (Tannen, 1990).

Although there is increased interest in social capital by researchers, there is little empirical evidence as to its role in the advancement of women to high management levels (Metz and Tharenou, 2001). Most of this research is focused on intraorganizational networks and women's access, or lack thereof (e.g., Cormier, 2007; Ibarra, 1993; Singh, Vinnicombe, and Kumra, 2006; Timberlake, 2005), rather than on patterns of interaction within the networks. Although women are seen as skillful in building informal strong networks with other women (Ibarra, 1993), they also often view networks as a luxury (Cormier, 2007) of time they can ill afford as they juggle work requirements with family responsibilities (O'Neil, Hopkins, and Bilimoria, 2008).

\section{Single-Sex Education}

If we are to accept the premise that gender disparity exists in both entrepreneurial and corporate environments, one might surmise that stereotyping and the resultant organizational structures have much to do with these disparities. There is much in the literature that supports this argument, as noted above.An examination of the literature on female adolescents might prove enlightening as to developmental issues that partially predetermine expectations for success, aspirations, and psychosocial elements of self-efficacy. An extensive literature review is outside the scope of this article, but one population - that of females who have attended single-sex educational institutions in relation to mixed-sex institutions-has been studied extensively as to the above expectations and elements for success.

There is not a definitive conclusion as to positive effects of a single-sex education. However, it is been shown that women's colleges outrank all other institutions of higher education in their production of women who go on to earn doctorates in the natural sciences and women who enter schools of medicine, fields customarily associated with masculine undertakings (Tidball, M. E, 1986; Tidball, M. E., 1985). In addition, in a Business Week's list of 50 women who are rising stars in corporate America, 30 percent received their baccalaureate degree from a women's college. One third of the women board members of the 1992 Fortune 1000 companies were women's college graduates, and 36 percent of the highest paid women officers of those companies were graduates of women's colleges. Finally, of 60 women members of Congress, 12 attended women's colleges ("Professional Achievements," Women's College Coalition, 2004). Ledman, Miller and Brown (1995), in an analysis of 126 successful women, also found that women's college graduates were more likely to be successful than female graduates of coeducational institutions.

The results of research on single-sex education are fraught with inconsistencies and are inconclusive. A disagreement appears to focus on the notion of separate but equal education and is, no doubt, a consequence of our increased attention to both the legality and/or discrimination toward women with regard to single-sex classes or education. Little research, in fact, has been conducted in the United States, where most single-sex education is now confined almost entirely to the private sector. These private institutions appear to be destined to become extinct, and the decrease in total numbers at present points less to academic reasons, and more to financial ones (Riordan, 1985; Astin, 1977).

As noted above, the results from overall efficacy of singlesex education are mixed. In 1985, Riordan reported that Catholic single-sex schools, on average, were nearly twice as effective as Catholic mixed-sex schools in terms of cognitive outcomes. This was true after controlling for race, socioeconomic status, sex, and geographic region. He found sufficient basis to expect that single-sex school advantages may be stronger for females than for males. Mixell (1989) examined 11 research studies and found that 8 of these investigations concluded that "coed schools, as a major part of the detrimental peer group society, exerted a stultifying influence on intellectual development when compared with single-sex schools" (p. 15). The Office of Educational Research and Improvement of the U.S. Department of Education, noted

... several studies indicate that girls enrolled in single-sex schools perform better on a variety of measures than their peers in coeducation schools; that boys may perform better in coeducational settings; and that other studies suggesting different outcomes for boys in single-sex Catholic high schools can be explained by differences in family background and initial ability" (Brake, 1999, p. 7).

Yet, in 2002, Riordan again wrote of the topic, and noted that by the 1980s and 1990s, the disadvantages for females in schools had been repaired, and now "only females of low socioeconomic status are likely to show significant gains (along with boys) in single-sex schools" (Riordan, 2002, p. 16). Other research also indicates that there is no advantage to single-sex education (e.g., Durost, 1996; Haag, 1998; Harker and Nash, 1997; LePore and Warren, 1996; Miller and Dale, 
1972; Pollard, 1999). Shmurak (1998), in her longitudinal study of a group of young women from the ninth grade through the first year of college, reported that for course grades, there were no significant differences between the girls who attended all-girls schools and those at coeducational schools on the following measures: grades in mathematics, science, and English, and overall academic average.

There does seem to be conflicting research regarding differences in math and science emphasis and scores-skills that are not only important for women entrepreneurs, but affect and are affected by their self-efficacy. Examples of research findings that report these differences are in Table 1.

With regard to aspirations, Lee and Marks (1990) researched the sustained effects of single-sex schools on attitudes, behaviors, and values. They found that women who had attended single-sex schools had higher educational aspirations and were more likely to be well satisfied with both the academic and nonacademic aspects of college life, in addition to being more likely to consider graduate school. Indeed, girls continue to consider and pursue a narrower set of career opportunities than do boys. "This inequity reverberates beyond school and into the labor force, where only 6 percent of women are in nontraditional careers. In fact, women cluster in only 20 of the more than 400 job categories, and two out of three minimum-wage earners are women" ("Gender Gaps: Where Schools Still Fail Our Children," 2000). Riordan (1994) found that women's college attendees achieved higher occupational positions and significantly higher salaries when compared with coeducated women of equivalent education level.

Tidball, et al. (1999) noted an interesting partial explanation for this difference: the relationship between the number of women faculty and the number of women students who subsequently became achievers. A study by M. E. Tidball (1973) was the first to demonstrate that the number of women faculty on campus is strongly and positively related to the production of women who become achievers regardless of baccalaureate origin. That is, the more women faculty, the more women students become achievers, regardless of institution type. Later, M. E. Tidball found that the larger the proportion of male students on campus, the less likely are women students subsequently cited for career achievement (1980). The importance of successful female role models does seem to be a crucial element in the development of gender identification. The camaraderie with other women developed throughout the college years in single-sex colleges conspires to form bonds that can last forever. Women have many opportunities to learn first-hand the competence of other women with whom they share the campus. As a result, these alumnae will later find themselves comfortable in respecting the talents and capabilities of their professional women colleagues. Thus, women's college alumnae will have key roles in the advancement of other women in their careers. In addition, the alumni associations for women's colleges are very active; the extensive career networks that are established add another ingredient to these women's career progress and success (Tidball et al., 1999).

Single-sex education also seems to facilitate learning for future leadership roles. Pascarella and Terenzini (1991), for example, proposed that women's colleges appear to provide a uniquely supportive climate for women to experience themselves and other females in a wide range of intellectual and social leadership roles. As Tidball, et al. (1999) comment in their support of women's colleges,

\begin{tabular}{|l|l|}
\hline \multicolumn{2}{|c|}{ Table 1. Math or Science Differences Found in Single-Sex Education } \\
\hline \multicolumn{1}{|c|}{ Author } & \\
\hline Pollard (1999) & $\begin{array}{l}\text { When girls and boys occupy the same classroom they can receive very different educational experiences. } \\
\text { These findings were particularly evident in math, science, and computer-related subjects. }\end{array}$ \\
\hline Haag (1998) & $\begin{array}{l}\text { Several studies in Great Britain and Nigeria found that girls in single-sex schools, in fact, may have stronger } \\
\text { preferences for subjects such as math and physics than their coed peers. }\end{array}$ \\
\hline Perry (1996) & $\begin{array}{l}\text { Reported that grade point averages in his study were higher for both girls and boys in single-sex math and sci- } \\
\text { ence classes than in mixed-sex classes. }\end{array}$ \\
\hline $\begin{array}{l}\text { Trickett, Trickett, Castro, and } \\
\text { Schaffner (1982) }\end{array}$ & $\begin{array}{l}\text { Students perceived single-sex schools as having more of an academic orientation than coeducational schools, } \\
\text { and more importance is placed on competition and task completion in the single-sex schools. }\end{array}$ \\
\hline Vockell and Lobonc (1981) & $\begin{array}{l}\text { The perception by girls of physical sciences as masculine was much more likely to occur in coed classes } \\
\text { than in all-female classes. In all-girls classes, females were not a deviant minority and could perform with- } \\
\text { out inhibition. }\end{array}$ \\
\hline Finn (1980) & $\begin{array}{l}\text { Male and female students have similar reading skills; however, males outperform females in science and males } \\
\text { have more positive attitudes toward science. }\end{array}$ \\
\hline Dale and Miller (1972) & $\begin{array}{l}\text { A comparison of the first-year progress of university students from single-sex and coeducational schools found } \\
\text { that in arts, there was equality, but in science, the coeducated made slightly better progress. It may be that this } \\
\text { trend has continued because of improved financing for, and focus on, math and science education. }\end{array}$ \\
\hline
\end{tabular}


The important finding may be not so much the evidence for experience in terms of numbers of activities, but rather the importance of providing an environment in which women participate fully in all kinds of leadership activities, women see women in leadership roles, and choices whether or not to participate are not mediated by gender (p. 64).

Further, a research effort by Lockheed (1976) investigated how the effect of a high school female's status in a mixedgender group of decision makers modified her leadership behaviors. The results indicated no difference between taskoriented activity for all-female and all-male groups. Naïve mixed-gender groups were dominated by males; mixed-gender groups of members who were experienced in a singlesex condition showed a more nearly equal distribution of activity for males and females. In other words, heterogeneous groups were dominated by male members unless the females were experienced in single-sex group activities.

For female students, the fear of success was significantly higher in coeducational schools than in single-sex schools (Winchel, Fenner, and Shaver, 1974). In addition, Holland and Eisenhart (1990) developed the theme of physical appearance as an important issue for females in coeducational institutions. The women in their study were constantly exposed to social evaluation on the basis of sexual attractiveness to men, and made life decisions in the shadow of that reality. They found that for these females, schoolwork and peer activities were viewed as competing domains. Finally, Smith, Morrison, and Wolf (1994) sampled college students and found differences in ratings of self-esteem and self-confidence for men and women: women rated themselves lower at the beginning of college than men and continued to do so throughout college. It appears that although both men's and women's self-confidence improve over time in college, men start out more confident than women and that difference increases over the four years in school.

Despite the shortcomings of research on single-sex education, there are some common threads, if tenuous, that become apparent. Smith (1996) noted three possible effects across studies for females in single-sex educational environments: this type of education may provide a comfortable place in which girls can learn and explore the world; they provide an opportunity for girls to consider issues of gender identity and the variety of roles girls and women can later achieve; and they may be particularly helpful to girls at the developmental level of early adolescence. We would add that these environments may provide a milieu and role models that promote intellectual and psychosocial maturity, as well as a training ground for the development of leadership skills that will be useful in later life.

\section{Conclusion}

So, what does all this mean for women entrepreneurs? Taken as a whole, women entrepreneurs are not so different from their corporate sisters. They tend toward the same leadership styles and ways of interacting with others (both subordinates and clients); they also experience a lack of role models, and possible lack of self-efficacy (see Table 2 for a summary). This should not be so surprising in light of the number of women entrepreneurs who often leave their corporate environments to try to escape the glass ceiling (Cormier, 2007).

It was not our intent to focus on whether women or men are better entrepreneurs or leaders. Although gendered leadership styles may be becoming more alike than different, it is apparent that differences exist and that perhaps these differences can be illuminated as to their origins by examining the results of the literature on female education. We are also not advocating single-sex education for women entrepreneurs; however, there are several interesting findings regarding

Table 2. Female Entrepreneurship and Women's Leadership Commonalities

\begin{tabular}{|l|l|}
\hline \multicolumn{1}{|c|}{ Female Entrepreneurship Literature Findings } & \multicolumn{1}{c|}{ Women's Leadership Literature Findings } \\
\hline $\begin{array}{l}\text { Leadership Style } \\
\text { - Shared participation in decision-making process (relational); infor- } \\
\text { mal; flat organizational structure } \\
\text { - Transformational leadership style } \\
\text { - Reluctance to delegate responsibility }\end{array}$ & $\begin{array}{l}\text { Leadership Style } \\
\text { Cooperative, nurturing, empowering, team oriented; } \\
\text { flat organizational structure } \\
\text { - Reliance on emotional as well as rational data }\end{array}$ \\
\hline $\begin{array}{l}\text { Interpersonal Relationships } \\
\text { - Business a cooperative set of networks or relationships } \\
\text { - Relational approach in interacting with employees and clients } \\
\text { - Networks important } \\
\text { - Lack of role models Shared participation in decision-making } \\
\text { process (relational); informal; }\end{array}$ & $\begin{array}{l}\text { Interpersonal Relationships } \\
\text { - Encourage participation, group identity among subordinates } \\
\text { - Lack of role models }\end{array}$ \\
\hline $\begin{array}{l}\text { Self-Efficacy } \\
\text { - Lack of confidence in quantitative abilities }\end{array}$ & \\
- Fear of failure & Self-Self Efficacy \\
\hline
\end{tabular}


female education relating to the commonalities mentioned in Table 2. A synthesis of the literature provides the following observations regarding the female single-sex educational experience:

- This environment appears to provide a setting where young women feel comfortable to perform without the inhibiting influence of competition from males and all the complexities that hormonal issues present.

- Young females also seem to hold less stereotyped views on gender in these institutions and hold higher aspirations than their coeducated sisters.

- The single-sex environment may also provide greater opportunities for the training of leadership skills.

- Increased self-confidence and efficacious attitudes may be the result of their exposure to a higher number of successful women role models-either through a predominantly female faculty or through female alumni. The bonding produced in this "community of women" appears to be a strong factor in the development of their networking skills, which proves helpful to them as they move out into the workforce.

It should be apparent from the dearth of literature in the above areas that there are ample topics for future research. For example, it would seem useful to further study single-sex environments to determine if there are specific practices within these environments that might predict future success in other environments. To date, the literature only points to actual numbers of successful women. It would be useful to follow up with these successful women to delve further into their success stories. Also, it would be interesting to note whether there is an unusually high percentage of women coming out of single-sex educational experiences and starting their own entrepreneurial firms.

It would seem important to further address the area of women's leadership within corporate versus entrepreneurial contexts. Female entrepreneurial leadership research is in its infancy, and few studies have been conducted comparing the two environments. If leadership opportunities in female adolescence increase self-efficacy in adulthood, we should be attending to the variables that enhance those adolescent experiences so that all young females are afforded the developmental opportunity for this important experience.

We should see much more research in the area of networks and communication patterns, since this may be a key to success for future women entrepreneurs. A basic question that needs to be answered is: Why do women use these networks and communication patterns? Does their use boost self-efficacy? Is it the medium that is comfortable, i.e., safety in numbers?

Research tells us there is definitely something about the "community" aspect of femaleness-whether it is learned, forced, or an opportunity - that helps women find success in their work lives. It does appear that there is value in studying the "community" aspect of femaleness further if there are some situations in which a single-sex environment may promote the self-efficacy of young women as they launch their careers or move into entrepreneurship. In addition, this focus could address whether the social networking skills developed then, and later, support the women as they move up their career ladders, whether as entrepreneurs or in the corporate world.

The results of this review have also provided some implications for expanding and rethinking the education of women entrepreneurs. At present, there are very few academic entrepreneurship courses or programs focused specifically toward women (Gundry, Ben-Yoseph, and Posig, 2002). Nevertheless, if these findings are accurate, women entrepreneurs have different goals than males in the leadership of their organizations. The profit motive is obviously strong for both genders; however, how women deal with the dynamics of interpersonal and support relationships, how they conduct environment scanning, and other methods of information gathering do appear to be at least qualitatively different.

At present, most entrepreneurship courses fail to address the nonfunctional topic of leadership adequately. It is most likely expected that students receive at least a modicum of exposure in organizational behavior courses, if required. Both male and female students come into an academic atmosphere woefully short of skills in social behaviors (e.g., business etiquette, networking, communication, and presentation) and little knowledge in the practical nuances of these behaviors. If women entrepreneurs find these social behaviors especially important in establishing and growing their businesses, educators would do well to provide practical experience for their female students before they embark on their ventures.

The issue of female self-confidence or self-efficacy may be the reflective of systemic problems with our educational system (and in fact, society in general) and will be more difficult to solve. The lack of successful role models for both women entrepreneurs and women in corporations may be attenuated "with time"; however, educators should be providing opportunities for females to learn from these exemplars.

The results of future research may also guide us to specific practices we can institute for young women that will enhance their entrepreneurial skills and behaviors in these areas. 


\section{References}

Adler, P. S., and Kwon, S. W. (2002). Social capital: Prospects for a new concept. Academy of Management Review 27, 17-40.

Allen, I. E., Elam,A., Langowitz, N., and Dean, M. (2008). 2007 report on women and entrepreneurship: Global Entrepreneurship Monitor (GEM). Accessed from www3.babson.edu/ESHIP/research-publications/upload/GEMWomen072.pdf.

Apfelbaum, E., and Hadley, M. (1986). Leadership Ms. - qualified: II. Reflections and initial case study investigation of contemporary women leaders. In C. Graumann \& S. Moscovici (Eds.), Changing Conceptions of Leadership. New York: Springer Verlag.

Appelbaum, S. H., Audet, L., and Miller, J. C. (2003). Gender and leadership? Leadership and gender? A journey through the landscape of theories. Leadership \& Organization Development Journal 24, 43-52.

Astin,A.W. (1977). Four Critical Years. Effects of College on Beliefs, Attitudes and Knowledge. San Francisco: Jossey Bass Publishers, Inc.

Baker,T., Aldrich, H. E., and Liou, N. (1997). Invisible entrepreneurs: The neglect of women business owners by mass media and scholarly journals in the USA. Entrepreneurship \& Regional Development 9, 221-238.

Betters-Reed, B. L., and Moore, L. L. (2007). Annotated bibliography on women business owners: A diversity lens. New England Journal of Entrepreneurship 10,33-58.

Bird, B. and Brush, C. (2002). A gendered perspective on organizational creation. Entrepreneurship Theory and Practice 26, 41-66.

Birley, S. (1989). Female entrepreneurs: Are they really any different? Journal of Small Business Management 27, 32-37.

Bobko, P. (1985). Removing assumptions of bipolarity:Towards variation and circularity. Academy of Management Review 10, 99-108.

Brake, D. L. (1999).A legal framework for single-sex education. Women's Educational Equity Act Resource Center Digest, October 4-8.

Brockner, J., and Adsit, L. (1986). The moderating impact of sex on the equity-satisfaction relationship:A field study.Journal of Applied Psychology 71, 585-590.

Brown, L. K. (1979). Women and business management. Journal of Women in Culture and Society 5, 266-288.

Brush, C. G. (1992). Research on women business owners: Past trends, a new perspective and future directions. Entrepreneurship Theory and Practice 16,5-30.

Brush, C. G., and Bird, B. J. (1996). Leadership vision of successful women entrepreneurs: Dimensions and characteristics. In W. D. Bygrave, B. J. Bird, S. Birley, N. C. Churchill, M. G. Hay, R. H. Kelley, \& W. E. Wetzel, Jr. (Eds.), Frontiers of Entrepreneurship Research. Summary. Wellesley, MA: Babson College. Online: www.babson.edu/entrep/fer/papers96/summ96/brush.html.

Brush, C. G., Carter, N. M., Gatewood, E. J., Greene, P. G., and Hart, M. M. (2004). Women entrepreneurs, growth, and implications for the classroom (Coleman Foundation White Paper Series): U.S. Association for Small Business and Entrepreneurship.

Buttner, E. H. (2001). Examining female entrepreneurs' management style:An application of a relational frame. Journal of Business Ethics 29, 253-269.

Buttner, E. H., and Moore, D. P. (1997). Women's organizational exodus to entrepreneurship: Self-reported motivations and correlates with success. Journal of Small Business Management 35, 34-47.

Carter, S. (2000). Improving the numbers and performance of women-owned businesses: Some implications for training and advisory services. Education E Training 42, 326-333.

Catalyst. (2007a). 2007 Catalyst Census of Women Board Directors. New York: Catalyst.

Catalyst. (2007b). 2007 Catalyst Census of Women Corporate Officers and Top Earners. New York: Catalyst.

Catalyst. (2000). Cracking the Glass Ceiling: Catalyst's Research on Women in Corporate Management, 1995-2000. New York: Catalyst.

Center for Women's Business Research. (2008). "Fact Sheet," www.womensbusinessresearch.org, accessed on April 18, 2008.

Chaganti, R. (1986). Management in women-owned enterprises. Journal of Small Business Management, October, $24,18-30$.

82 NEW ENGLAND JOURNAL OF ENTREPRENEURSHIP 
Corsun, D. L., and Costen, W. M. (2001). Is the glass ceiling unbreakable? Habitus, fields, and the stalling of women and minorities in management. Journal of Management Inquiry 10, 16-26.

Cormier, D. (2007). Retaining top women business leaders: Strategies for ending the exodus. Business Strategy Series 8 , 262-271.

Cowling, M., and Taylor, M. (2001). Entrepreneurial women and men:Two different species? Small Business Economics 16, 167.

Daily, C. M., Certo, S.T., and Dalton, D. R. (1999). Entrepreneurial ventures as an avenue to the top? Assessing the advancement of female CEOs and directors in the Inc. 100. Journal of Developmental Entrepreneurship 4, 19-32.

Dale, R. R. \& Miller, P. McC. (1972). The academic progress of university students from co-educational and single-sex schools. British Journal of Education Psychology 42,317-319.

Davidson, M. J. \& Cooper, C. L. (1992). Shattering the Glass Ceiling:The Woman Manager. London: Paul Chapman.

Davidsson, P., and Honig, B. (2003). The role of social and human capital among nascent entrepreneurs. Journal of Business Venturing 18, 301-331

deBruin, A., Brush, C. G., and Welter, F. (2007). Advancing a framework for coherent research on women's entrepreneurship. Entrepreneurship Theory \& Practice 31,323-339.

DeCarlo, J. F, and Lyons, P. R. (1979). A comparison of selected personal characteristics of minority and non-minority female entrepreneurs. Journal of Small Business Management 17, 22-29.

Des Jardins, Jory. (2005). I am woman (I think). Fast Company, May, 25-26.

Durost, R.A. (1996). Single sex math classes: What and for whom? One school's experience. NASSP Bulletin, 80, 577, February, pp. 27-31.

Eagly, A. H., Johannesen-Schmidt, M. C., and van Engen, M. L. (2003). Transformational, transactional, and laissez-fair leadership styles:A meta-analysis comparing women and men. Psychological Bulletin 129, 569-591.

Eagly, A. H., and Johnson, B.T. (1990). Gender and leadership style:A meta-analysis. Psychological Bulletin 108, $233-256$.

Eagly, A. H., Karau, S. J., and Makhijani, M. G. (1995). Gender and the effectiveness of leaders: A meta-analysis. Psychological Bulletin 117, 125-145.

Eccles, J. S. (1987). Gender roles and women's achievement-related decisions. Psychology of Women, 11, 135-171.

Ely, R. J. (1994). The effects of organizational demographics and social identity on relationships among professional women. Administrative Science Quarterly 39, 203-239.

Epstein, C. F. (1991). Ways men and women lead. Harvard Business Review, January-February, 150-160.

Fagenson, E.A., and Marcus, E. C. (1991). Perceptions of the sex-role stereotypic characteristics of entrepreneurs: Women's evaluations. Entrepreneurship Theory \& Practice 15, 33-47.

Federal Glass Ceiling Commission. (1995). A solid investment: Making full use of the nation's human capital. Department of Labor.

Finn, J. D. (1980). Sex differences in educational outcomes: A cross-national study. Sex Roles: A Journal of Research, 6, 9-26.

"Gender Gaps: Where Schools Still Fail Our Children." AAUW Website, www.aauw.org/2000/ggbod.html, accessed 2/19/03.

Gilligan, C. (1982). In a Different Voice: Psychological Theory and Women's Development. Cambridge: Harvard University Press.

Goleman, D. (1995). Emotional Intelligence:Why It Can Matter More than IQ. New York: Bantam.

Goodstadt, B., and Kipnis, D. (1970). Situational influences on the use of power. Journal of Applied Psychology 54, 201-207.

Green, P. G., Hart, M. M., Gatewood, E. J., Brush, C. G., and Carter, N. M. (2003). Women Entrepreneurs: Moving front and center: An overview of research and theory. Whitepaper, USASBE website, www.usasbe.org.

Gundry, L. K., Ben-Yoseph, M., and Posig, M. (2002). The status of women's entrepreneurship: Pathways to future entrepreneurship development and education. New England Journal of Entrepreneurship 5, 39-50.

Haag, P. (1998). K-12 single-sex education: What does the research say? Separated by sex: A critical look at single-sex education for girls. Washington, DC, American Association of University Women Education Foundation (in ERIC DIGEST, September 2000). 
Harker, R. and Nash, R. (1997). School type and the education of girls: Co-ed or girls only? Paper presented at the Annual Meeting of the American Educational Research Association, March 24-28. ERIC Document: ED 410633.

Hart, S. L., and Quinn, R. E. (1993). Roles executives play: CEOs, behavioral complexity, and firm performance. Human Relations 45, 543-574.

Helfat, C. E., Harris, D., and Wolfson, P. J. (2006). The pipeline to the top:Women and men in the Top executive ranks of U.S. corporations. Academy of Management Perspectives 20, 42-64.

Helgensen, S. (1990). The Female Advantage:Women's Ways of Leadership. New York: Doubleday.

Heilman, M.E., Block, C. J., Martell, R. F., and Simon, M. C. (1989). Has anything changed? Current characterizations of men, women, and managers. Journal of Applied Psychology 74, 935-942.

Holland, D. C., and Eisenhart, M. A. (1990). Education in Romance:Women, Achievement, and College Culture. Chicago: The University of Chicago Press.

Ibarra, H. (1993). Personal networks of women and minorities in management:A conceptual framework. Academy of Management Review 18, 56-87.

Ibarra, H. (1995). Race, opportunity, and diversity of social circles in managerial networks. Academy of Management Journal $38,673-704$.

Ibarra, H., and Andrews, S. B. (1993). Power, social influence, and sense-making: Effects of network centrality and proximity on employee perceptions. Administrative Science Quarterly 38, 277-304.

Katz, D., and Kahn, R. (1978). The Social Psychology of Organization. New York:Wiley.

Klenke, K. (1996). Women and Leadership:A Contextual Perspective. New York: Springer Publishing Co., Inc.

Klyver, K., and Terjesen, S. (2007). Entrepreneurial network composition:An analysis across venture development stage and gender. Women in Management Review 22, 682.

Korac-Kakabadse, A., Korac-Kakabadse, N., and Myers, A. (1998). Demographics and leadership philosophy: Exploring gender differences. The Journal of Management Development 17, 351-388.

Kourilsky, M. L., and Walstad, W. B. (1998). Entrepreneurship and female youth: Knowledge, attitudes, gender differences, and educational practices. Journal of Business Venturing 13,77-88.

Langowitz, N., and Minniti, M. (2007). The entrepreneurial propensity of women. Entrepreneurship Theory \& Practice 31, 341-364.

Ledman, R. E., Miller, M., and Brown, D. R. (1995). Successful women and women's colleges: Is there an intervening variable in the reported relationship? Sex Roles: A Journal of Research 33, 7-8, October, 489-497.

Lee, V. E., and Marks, H. M. (1990). Sustained effects of single-sex secondary school experience on attitudes, behaviors and values in college. Journal of Educational Psychology 82, 578-592.

Lenney, E., Gold, J., and Browning, C. (1983). Sex differences in self-confidence:The influence of comparison to others' ability level. Sex Roles 9, 925-942.

Loden, M. (1985). Feminine leadership: Or how to succeed in business without being one of the boys. New York:Times.

LePore, P. C, and Warren, J. R. (1996). The advantages of single-sex Catholic secondary schooling: Selection effects, school effects or "Much ado about nothing?" Paper Presented at the Annual Meeting of the American Educational Research Association, April 8-12. ERIC Document: ED 402325.

Lockheed, M. E. (1976). The modification of female leadership behavior in the presence of males. Report prepared for the U.S. Department of Health, Education and Welfare, National Institute of Education.

Loomis, C. J. (2005). How the HP Board KO'd Carly. Fortune, March 7, 99-102.

Mast, M. S. (2005). The world according to men: It is hierarchical and stereotypical. Sex Roles 33, 919-924.

McClelland, D. (1975). Power: The Inner Experience. New York: Irvington.

Menzies, T. V., Diochon, M., and Gasse, Y. (2004). Examining venture-related myths concerning women entrepreneurs. Journal of Developmental Entrepreneurship 9, 89-107.

Metz, I., and Tharenou, P. (2001). Women's career advancement: The relative contribution of human and social capital. Group and Organization Management, 26, 312-343. 
Meyerson, D. E., and Fletcher, J. K. (2002). A modest manifesto for shattering the glass ceiling. Harvard Business Review, January-February, 127-136.

Miller, J. B. (1976). Toward a New Psychology of Women. Boston: Beacon Press.

Mixell, D. J. (1989). An annotated bibliography of the research comparing academic achievement and attitudes of students in coeducational and single-sex secondary schools. Unpublished paper, Indiana University at South Bend. Eric Database, Document No. ED 312185.

Moore, D. P. (1990). An examination of present research on the female entrepreneur-Suggested research strategies for the 1990s. Journal of Business Ethics 9, 275-281.

Moore, D. P. (1999). Women Entrepreneurs:Approaching a New Millennium. In G.Powell (Ed.) Handbook of Gender and Work. Thousand Oaks: Sage Publications, 371-389.

Moore, D. P. (2004). The entrepreneurial woman's career model: Current research and a typological framework. Equal Opportunities International 23, 78-98.

Mowday, R.T. (1979). Leader characteristics, self-confidence, and methods of upward influence in organizational decision situations. Academy of Management Journal 22, 709-725.

Mueller, S. L., and Dato-on, M. C. (2008). Gender-role orientation as a determinant of entrepreneurial self-efficacy. Journal of Developmental Entrepreneurship 13, 3-20.

Mukhtar, S. M. (2002). Differences in male and female management decisions:A study of owner-manager businesses. Small Business Economics, June, 18(4), 289-311.

Nahapiet, J., and Ghoshal, S. (1998). Social capital, intellectual capital, and the organizational advantage. Academy of Management Review 23, 242-266.

Neider, L. (1987). A preliminary investigation of female entrepreneurs in Florida.Journal of Small Business Management $25,22-29$.

Nieva,V. F., and Gutek, B.A. (1980). Sex effects on evaluation. Academy of Management Review 5, $267-276$.

Nixdorff, J. L. (2008). Unraveling the process: A qualitative study of entrepreneurial cognition in opportunity recognition. Dissertation Abstracts International (UMI No. 3310975).

O'Neil, D.A., Hopkins, M. M., and Bilimoria, D. (2008). Women's careers at the start of the 21st century: Patterns and paradoxes.Journal of Business Ethics 80, 727-743.

Pascarella, E. T., and Terenzini, P. T. (1991). How College Affects Students: Findings and Insights from Twenty Years of Research. San Francisco: Jossey-Bass Publishers.

Perry, W. C. (1996). Gender-based education: Why it works at the middle school level. NASSP Bulletin 80, 32-35.

Pollard, D. S. (1999). Single-sex education. Women's Educational Equity Act Resource Center Digest, October, 2.

Portes, A. (1998). Social capital: Its origins and applications in modern sociology. Annual Review of Sociology 24, 1-24.

Powell, G. N. and Butterfield, D.A. (1979). The "good manager": Masculine or androgynous? Academy of Management Journal 22, 395-403.

Powell, G. N., Butterfield, D.A., and Parent, J. D. (2002). Gender and managerial stereotypes: Have the times changed? Journal of Management 28, 177-193.

"Professional Achievements,"Women's College Coalition website: www.womenscolleges.org, accessed on 1/27/04.

Ragins, B. R., and Sunstrom, E. (1989). Gender and power in organizations:A longitudinal perspective. Psychological Bulletin 105(1) 51-88.

Renzulli, L.A.,Aldrich, H. E., and Moody, J. (2000). Family matters: Gender, networks, and entrepreneurial outcomes. Social Forces 79, 523-546.

Riordan, C. (1985). Public and Catholic Schooling. American Journal of Education 93, 518-540.

Riordan, C. (1994). The value of attending a women's college: Education, occupation and income benefits.Journal of Higher Education 65, 486-510.

Riordan, C. (2002). What do we know about the effects of single-sex schools in the private sector? Implications for public schools. In A. Datnow \& L. Hubbard (Eds.), Gender in policy and practice: Perspectives on single-sex and coeducational schooling (pp. 10-30). New York: RoutledgeFalmer. 
Rosen,T.H. (in press). Perceiving Disagreement.

Rosener, J. (1990). Ways women lead. Harvard Business Review, November-December, 119-125.

Rost, J. (1991). Leadership for the 21st Century. New York: Praeger.

Schwartz, E. B. (1976). Entrepreneurship:A new female frontier. Journal of Contemporary Business, Winter, 5, 47-76.

Shmurak, C. B. (1998). Voices of hope:Adolescent girls at single sex and coeducational schools. New York: Peter Lang Publishing.

Singh, V., Vinnicombe, S., and Kumra, S. (2006). Women in formal corporate networks:An organisational citizenship perspective. Women in Management Review 21, 458-482.

Smeltzer, L. R., and Fann, G. L. (1989). Gender differences in external networks of small business. Journal of Small Business Management 27, 25-32.

Smith, D. G., Morrison, D. E., and Wolf, L. E. (1994). College as a gendered experience:An empirical analysis using multiple lenses. Journal of Higher Education 65, 696-725.

Smith, I. D. (1996). The impact of coeducational schooling on student self-concept and achievement. Paper presented at the Biennial Meeting of the International Society for the Study of Behavioral Development, Quebec, Canada, August 12-16. ERIC Document: ED 400090.

Srinivasan, R., Woo, C.Y., and Cooper, A. C. (1994). Performance determinants for male and female entrepreneurs. In W. D. Bygrave, S. Birley, N.C. Churchill, E. Gatewood, F. Hoy, R. Keeley, \& W. E. Wetzel, Jr. (Eds.), Frontiers of Entrepreneurship Research. Wellesley, MA: Babson College.

Statham, A. (1987).The gender model revisited: Differences in the management styles of men and women. Sex Roles 16, 409-429.

Stevenson, L. (1990). Some methodological problems associated with researching Women entrepreneurs. Journal of Business Ethics 9, 439-446.

Stevenson, L.A. (1986). Against all odds:The entrepreneurship of women. Journal of Small Business Management 24, 30-37.

Tannen, D. (1990). You just don't understand:Women and men in conversation. New York: Morrow.

Tidball, M. E. (1973). Perspective on academic women and affirmative action. Educational Record 54, 130-135.

Tidball, M. E. (1980). Women's colleges and women achievers revisited. Signs:Journal of Women in Culture and Society 5 , 504-517.

Tidball, M. E. (1985). Baccalaureate origins of entrants into American medical schools. Journal of Higher Education 56, 385-402.

Tidball, M. E. (1986). Baccalaureate origins of recent natural science doctorates. Journal of Higher Education 57, 606-620.

Tidball, M. E., Smith, D. G., Tidball, C.S., and Wolf-Wendel, L. E. (1999). Taking women seriously: Lessons and legacies for educating the majority. Phoenix:The Oryx Press.

Timberlake, S. (2005). Social capital and gender in the workplace. The Journal of Management Development 24, 34-45.

Trickett, E. J., Trickett, P. K., Castro, J. J., and Schaffner, P. (1982). The independent school experience:Aspects of the normative environments of single-sex and coed secondary schools. Journal of Educational Psychology 74, 374-381.

Vecchio, R. P. (2002). Leadership and gender advantage. The Leadership Quarterly 13, 643-671.

Verheul, I. (2002). Gender differences in strategy and human resource management. International Small Business Journal 20, 443-476.

Vockell, E. L., and Lebonc, S. (1981). Sex-role stereotyping by high school females in science.Journal of Research in Science Teaching 18, 209-219.

Von Glinow, M.A., and Mercer, A. K. (1988). Women in corporate America:A caste of thousands. New Management 6, 36-43.

Watson, C. (1988). When a woman is the boss: Dilemmas in taking charge. Group \& Organization Studies 13, 163-181.

Wilson, F., Kickul, J., and Marlino, D. (2007). Gender, entrepreneurial self-efficacy, and entrepreneurial career intensions:

Implications for entrepreneurship education. Entrepreneurship Theory \& Practice 31, 387-405. 
Wilson, F., Marlino, D., and Kickul, J. (2004). Our entrepreneurial future: Examining the diverse attitudes and motivation of teens across gender and ethnic identity.Journal of Developmental Entrepreneurship, 9, 177-197.

Winchel, R., Fenner, D., and Shaver, P. (1974). Impact of coeducation on "fear of success" imagery expressed by male and female high school students. Journal of Educational Psychology 66, 726-730.

Yammarino, F. J., Dubinski,A. J., Comer, L. B., and Jolson, M.A. (1997). Women and transformational and contingent reward leadership:A multiple-levels-of-analysis perspective. Academy of Management Journal 40, 205-222.
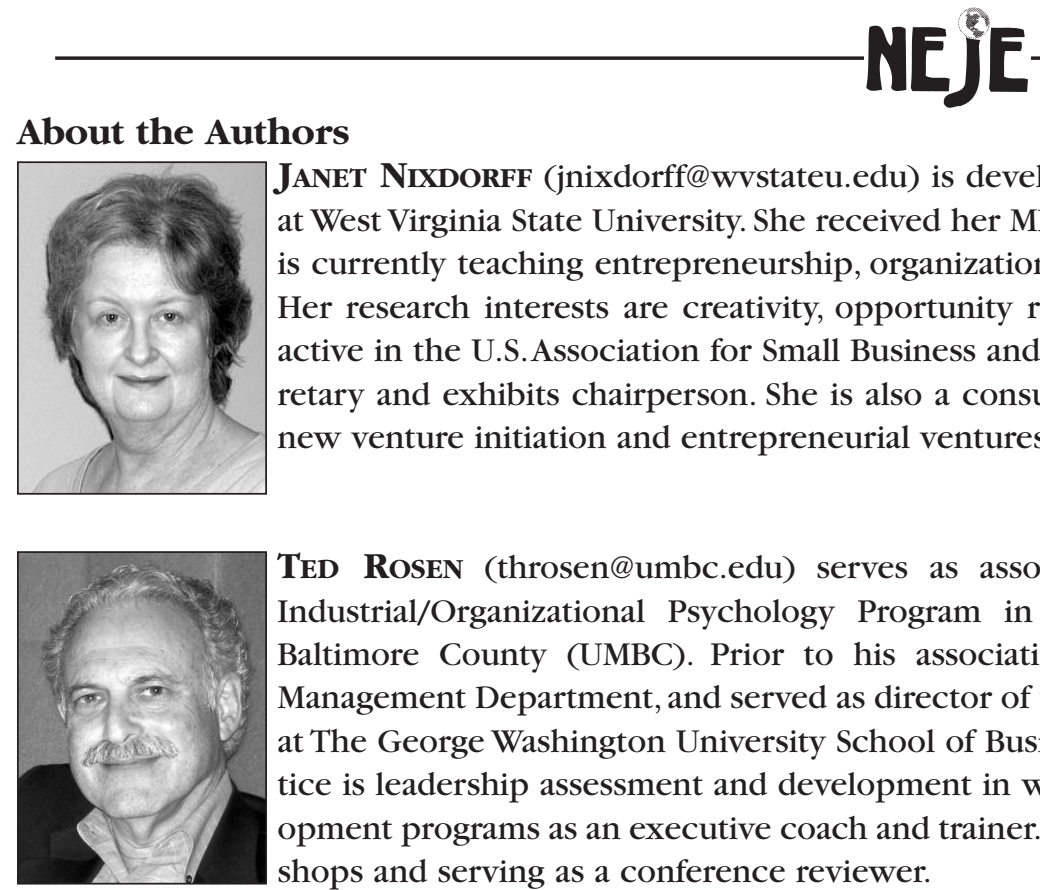

TED Rosen (throsen@umbc.edu) serves as associate program director and the director of the MPS: Industrial/Organizational Psychology Program in the Psychology Department, University of Maryland, Baltimore County (UMBC). Prior to his association with UMBC, Dr. Rosen was on the faculty of the Management Department, and served as director of the Program in Organizational Behavior and Development at The George Washington University School of Business. One particular area of Dr. Rosen's interest and practice is leadership assessment and development in working with the Center for Creative Leadership on development programs as an executive coach and trainer. Dr. Rosen has been active in the USASBE presenting workshops and serving as a conference reviewer.

He and Dr. Nixdorff have made joint presentations and led workshops on entrepreneurship, and creativity and innovation. Dr. Rosen recently published an article, "Improving communication awareness and management of perceiving disagreement," in the Review of International Comparative Management. 